\title{
OPEN Application of small molecule FPR1 antagonists in the treatment of cancers
}

\author{
Djevdet S. Ahmet ${ }^{1}$, Haneen A. Basheer ${ }^{2}$, Anwar Salem ${ }^{1}$, Di Lư ${ }^{1}$, Amin Aghamohammadi ${ }^{1}$, \\ Patrick Weyerhäuser ${ }^{3}$, Andrea Bordiga ${ }^{4}$, Juman Almeniawi ${ }^{1}$, Sabah Rashid ${ }^{1}$, \\ Patricia A. Cooper ${ }^{1}$, Steven D. Shnyder ${ }^{1}$, Victoria Vinader ${ }^{1}$ \& Kamyar Afarinkia ${ }^{1}$
}

The formylpeptide receptor-1 (FPR1) is a member of the chemotactic GPCR-7TM formyl peptide receptor family, whose principle function is in trafficking of various leukocytes into sites of bacterial infection and inflammation. More recently, FPR1 has been shown to be expressed in different types of cancer and in this context, plays a significant role in their expansion, resistance and recurrence. ICT12035 is a selective and potent ( $30 \mathrm{nM}$ in calcium mobilisation assay) small molecule FPR1 antagonist. Here, we demonstrate the efficacy of ICT12035, in a number of 2D and 3D proliferation and invasion in vitro assays and an in vivo model. Our results demonstrate that targeting FPR1 by a selective small molecule antagonist, such as ICT12035, can provide a new avenue for the treatment of cancers.

The formylpeptide receptors, of which there are three isoforms, FPR1, FPR2 (formerly known as FPRL1 and also known as ALX) and FPR3 (formerly known as FPRL2), belong to the cell surface chemotactic GPCR-7TM family. FPRs are primarily involved in leukocyte migration to the sites of bacterial infections ${ }^{1}$. For example, FPR1, which is the most common of the three, is expressed on a variety of leucocytes including monocytes and macrophages ${ }^{2,3}$, neutrophils $\mathrm{s}^{2,3}$, immature dendritic cells ${ }^{4}$, natural killer cells ${ }^{5}$, and $\mathrm{T} \mathrm{cells}^{6}$. Leukocytes respond after their FPR1 receptors are activated by molecules which are released at the site of infection as a result of bacterial or tissue necrosis and damage $\mathrm{e}^{7,8}$. These molecules include short chain $\mathrm{N}$-formylated peptides such as $\mathrm{N}$-formyl-L-methionyl-L-leucyl-L-phenylalanine (fMLF) ${ }^{9,10}$ and annexin A1 (ANXA1) 11,12 .

More recently, investigations have revealed that FPR1 also plays an important role in cancer. Although the expression of FPR1 in healthy, non-immune human cells is low ${ }^{13-15}$, it has been shown that a number of tumours express significant levels of FPR1. These include high grade glioblastoma ${ }^{16-18}$, neuroblastoma ${ }^{19}$, colon $^{13,20}$, breast $^{21}$, and bladder ${ }^{22}$ cancers. We should however note that in gastric cancer the role of FPR1 remains ambiguous. While FPR1 expression has been associated with poor prognosis in gastric cancer and correlated with tumour stage in one report ${ }^{23}$, another report suggested FPR1 expression suppresses gastric cancer angiogenesis and correlates with survival ${ }^{24,25}$. In addition, FPR1 is shown to contribute to the expansion of different tumour types. For instance, knock down of FPR1 reduces the ability of glioblastoma U87-MG tumour xenografts to grow ${ }^{26}$. Ye has shown that $\mathrm{FPR}^{-/-}$mice have increased survival compared with $\mathrm{FPR}^{+/+}$littermates in a colorectal cancer mode ${ }^{20}$. Finally, Vecchi and Goulart have shown that immunosuppressant cyclosporine A, which is also a weak antagonist of FPR1 $\left(\mathrm{IC}_{50}=2-4 \mu \mathrm{M}\right.$ in calcium mobilisation assay ${ }^{27}$ ), retards tumour growth and invasiveness in a breast cancer in vivo model ${ }^{21}$. Whilst these studies suggest a direct role for FPR1 in tumour growth, evidence in ovarian ${ }^{28}$, glioma ${ }^{17}$ and bladder cancers ${ }^{22}$ as well as acute lymphoblastic leukaemia ${ }^{29}$, has suggested that FPR1 is also involved in resistance and recurrence.

In spite of the accumulating evidence supporting a role for FPR1 in cancer, as yet no small molecule specifically targeting FPR1 has been tested for in vivo efficacy in a tumour model. ICT12035 belongs to a class of previously published, potent and selective family of FPR1 antagonists ${ }^{30}$ which are now being further investigated in our lab. ICT12035 is a potent $\left(\mathrm{IC}_{50}=30 \mathrm{nM}\right.$ in a calcium mobilisation assay), selective ( $>100$ fold versus FPR2), and non-cytotoxic (cell viability above $95 \pm 5 \%$ at $100 \mu \mathrm{M}$ ) FPR1 antagonist (see Supplementary Information).

\footnotetext{
${ }^{1}$ Institute of Cancer Therapeutics, University of Bradford, Richmond Road, Bradford BD7 1DP, UK. ${ }^{2}$ Faculty of Pharmacy, Zarqa University, PO Box 132222, Zarqa 13132, Jordan. ${ }^{3}$ Institut für Toxikologie, Universitätsmedizin

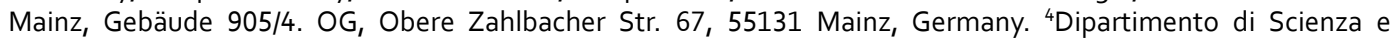
Tecnologia del Farmaco, Universitá Degli Studi di Torino, Via P. Giuria 9, 10125 Torino, Italy. ${ }^{\varpi}$ email: k.afarinkia@ bradford.ac.uk
} 
Here we show that ICT12035 reduces proliferation and invasion of cancer cell lines in a number of 2D and 3D assays, and retards growth of tumours in an in vivo xenograft model.

\section{Results \\ FPR1 is expressed in cancer cell lines, and its expression is elevated in the periphery of tumour's hypoxic/necrotic foci. We first determined the protein level expression of FPR1 in various} cancer cell lines, using flow cytometry. Expression of FPR1 was detected in the following human cancer cell lines: U87-MG (glioblastoma), PC-3, DU-145, LnCap (prostate), SH-SY-5Y (neuroblastoma), K-562 (chronic myelogenous leukaemia), HCT-116, SW620, SW480 and HT-29 (colorectal), A549 (lung) and MDA-MB-231 (breast) (Fig. 1A). We also showed that that in addition to being present in these cell lines, the receptor is functionally active and responds to FPR1 agonist $\mathrm{fMLF}$ in a $\mathrm{Ca}^{2+}$ mobilisation assay (Fig. 1B). Furthermore, this response to fMLF is abrogated by the selective and potent FPR1 antagonist, ICT12035 (Fig. 1B, only PC-3, SH-SY-5Y and HCT-116 data are shown as examples).

Walenkamp has previously shown that expression of FPR1 in human glioblastoma cells depends on the tumour microenvironment ${ }^{31}$. In view of this, we also confirmed the expression of FPR 1 in cancer cells grown as xenografts in mice by immunohistochemistry (IHC) (Fig. 1C, PC-3 and DU145 are shown as examples) (Fig. 1C).

We chose to study the efficacy of FPR1 antagonist ICT12035 in vitro and in vivo in the glioblastoma cell line, U87-MG. As we discussed earlier, the relevance of FPR1 as a target is shown in a number of cancers ${ }^{13,16-26,28,29}$. However, the expression and the relevance of FPR1 in glioblastoma is established in multiple sources ${ }^{31,32}$. In addition focusing on new treatment approaches to glioma is important, as it remains a particularly challenging cancer to treat. U87-MG cells do express FPR1 (Fig. 1A) and also respond to both known agonists of FPR1, fMLF $\left(\mathrm{EC}_{50}=80 \mathrm{nM}\right.$ in calcium flux) (Fig. 1D) and ANXA1(2-26) $\left(\mathrm{EC}_{50}=1 \mu \mathrm{M}\right.$ in calcium flux, in a dose dependant manner in a calcium flux assay. A dose response curve in calcium mobilisation assay (also known as calcium flux assay) showed ICT12035 antagonised the activation of FPR1 receptor by $100 \mathrm{nM}$ fMLF with an $\mathrm{IC}_{50}$ of $30 \mathrm{nM}$ (Fig. 1E).

Before using the U87-MG cell line as an in vitro model, we decided to investigate the expression of FPR1 in this cell line in 2D as well as 3D models. It is already known that $3 \mathrm{D}$ models such as multicellular spheroids recapitulate the conditions experienced by cancer cells within tumours' hypoxic/necrotic regions, more closely than in 2D models, such as monolayer cells.

Indeed, we found that the level of FPR1-expression in U87-MG cell line in 2D culture increased under hypoxic and serum deprivation stress conditions, which correlate to those experienced within the tumour's core (Fig. 2A). Furthermore, we investigated the expression of FPR1 in sections from formalin-fixed paraffin-embedded (FFPE) spheroids of U87-MG cells. In smaller spheroids with diameter below 400 micron, the levels of expression of FPR1 remained uniform across the whole section. However, in spheroids with diameter greater than 500 micron, which did contain a necrotic core (Fig. 2B-D), we observed a higher level of FPR1 expression in the periphery of the hypoxic/necrotic core of the spheroids. To determine if the same observation applies in vivo, we examined the levels of expression of FPR1 in U87-MG cells grown as subcutaneous xenografts. Again, we observed a higher level of FPR1 expression in the periphery of the hypoxic/necrotic core of the xenoplanted tumour (Fig. 2E).

ANXA1 is released from the hypoxic/necrotic core of 3D U87-MG multicellular spheroids. It has been previously established that ANXA1 is present in the supernatant of artificially necrotised glioma cells and that ANXA1 protein within these necrotic supernatant, can stimulate tumour cell growth and migration through binding to FPR1 receptor ${ }^{16,33}$. In view of this and our earlier observation that FPR1 expression is elevated in the periphery of the hypoxic/necrotic core of spheroids, we wanted to determine if ANXA1 is also released from the hypoxic/necrotic core of spheroids. Using ELISA, we quantified and compared the levels of ANXA1 in the supernatant of U87-MG cells grown as 3D spheroids and as 2D monolayers (Fig. 3A). We confirmed a correlation between the quantity of excreted ANXA1 in the medium and the number of cells in both 2D (monolayer) and 3D (spheroid) systems. However, the cell culture supernatants containing spheroids contained more ANXA1 than those with the same number of corresponding cells cultured as monolayer and that difference increased for larger spheroids. The larger spheroids were subsequently isolated and shown to contain a bigger hypoxic/necrotic core. This observation strongly supports the hypothesis that ANXA1 released from the hypoxic/necrotic core diffuses out of spheroids' core and can activate the FPR1 receptors which are in the periphery cells of the hypoxic/necrotic core. Furthermore, we confirmed the previous observation that ANXA1 is expressed in the U87-MG cells grown as subcutaneous xenografts (Fig. 3B,C).

ICT12035 reduces fMLF-induced increases in proliferation in 2D and 3D culture. We next showed that activation of the FPR1 receptor results in increased proliferation in U87-MG cells. Addition of fMLF, which is a more potent agonist of FPR1 than ANXA1, to U87-MG cells grown as monolayers increased rate of cell proliferation. However, administration of the selective FPR1 antagonist ICT12035, at the same time as fMLF, abrogated the observed increase in cell numbers (Fig. 4A).

As $2 \mathrm{D}$ models do not accurately recapitulate the conditions experienced by cells within tumours, we also measured growth of U87-MG multicellular spheroids as determined by increases in their volume. Pre-formed spheroids with diameters in the range of 100-120 microns $(n=8)$ were treated with PLF and control, and with ICT12035 and control (Fig. 3B). The spheroids' growth was monitored by measuring the total volume of each spheroid at $146 \mathrm{~h}, 172 \mathrm{~h}$ and $197 \mathrm{~h}$ using a Celigo Imaging Cytometer (Nexcelom) ${ }^{34}$. We observed a statistically significant increase in the spheroid volume at both $172 \mathrm{~h}$ and $197 \mathrm{~h}$ upon fMLF treatment compared to control. However, that increase was significantly retarded upon addition of ICT12035 (Fig. 4B). 

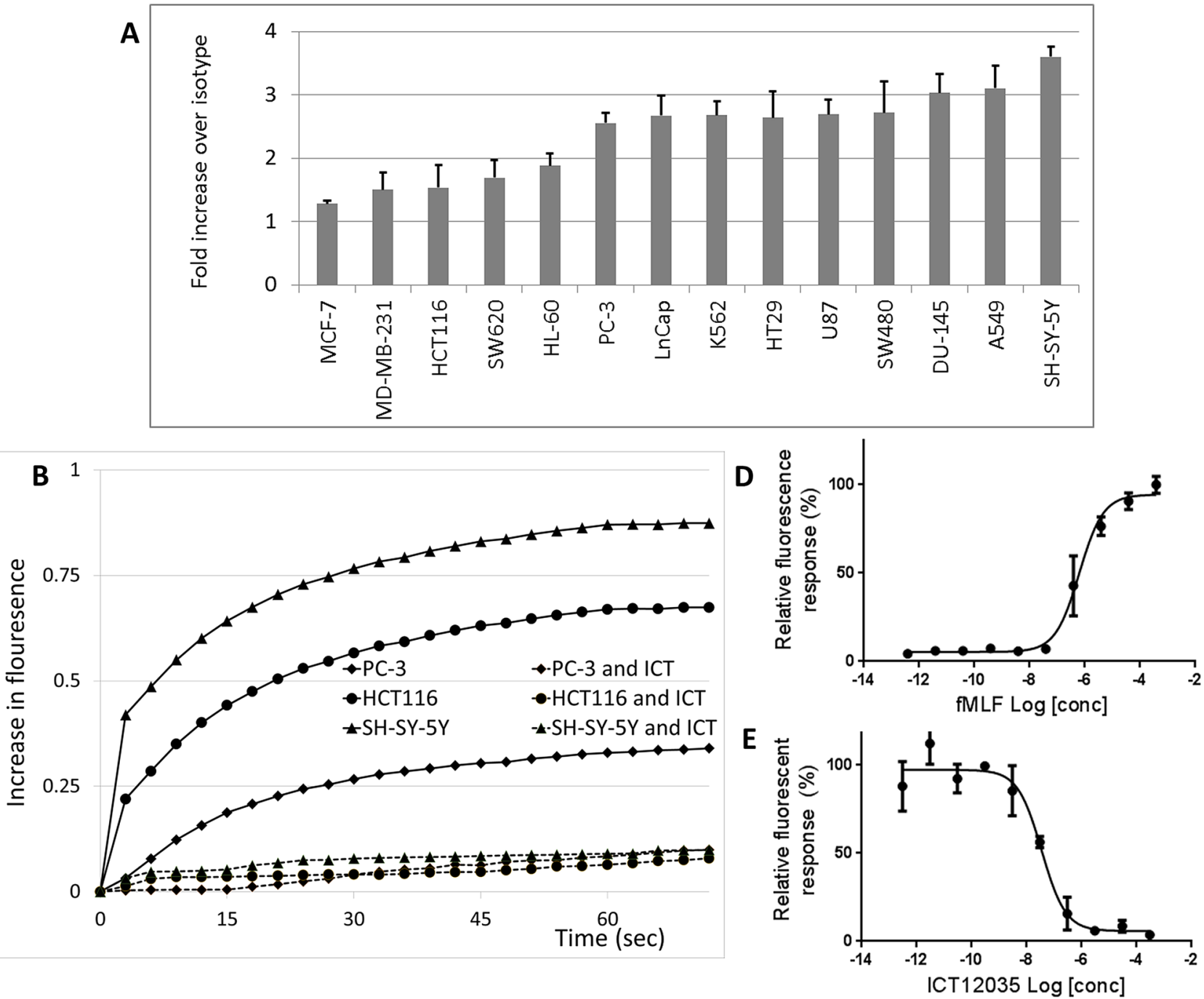

C
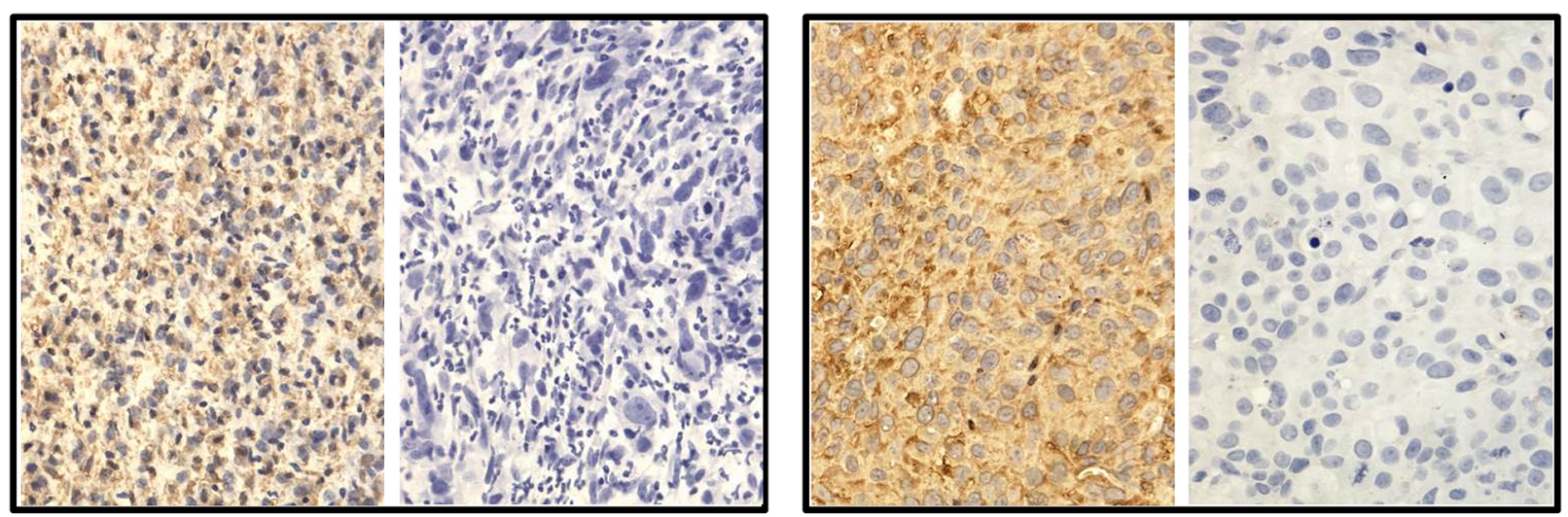

PC3

DU145

Figure 1. (A) Fold expression of FPR1 over control (isotype antibody) in different cell lines as determined by flow cytometry. (B) Relative fluorescence response in $\mathrm{Ca}^{2+}$ mobilisation (flux) assay to FPR1 agonist fMLF (100 nM) in the presence or absence of FPR1 antagonist ICT12035 $(1 \mu \mathrm{M})$ for cell lines PC3, HCT-116 and SH-SY-5Y. (C) Expression of FPR1 by immunohistochemistry (IHC) in sections from PC3 and DU145 xenotransplanted tumour tissue (with and without antibody). Basophilic structure of cell was stained in blue with haematoxylin solution. (D) Dose response curve for U87-MG cells over concentration range of fMLF (agonist mode). (E) Dose response curve for U87-MG cells over concentration range of ICT12035 after treatment with $100 \mathrm{nM}$ fMLF (antagonist mode). 
A

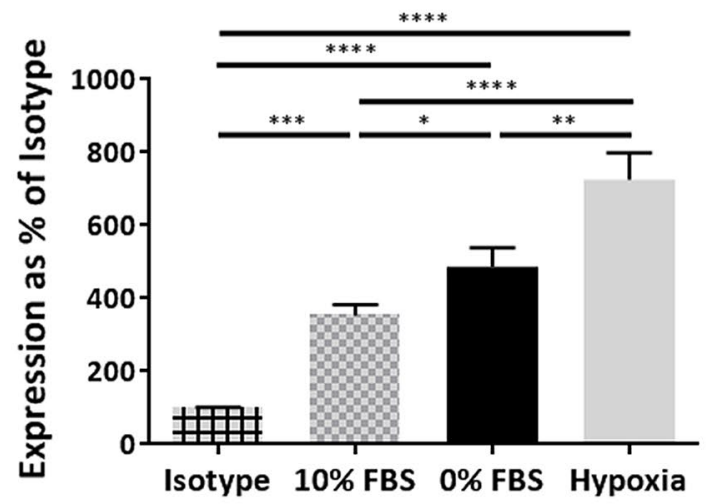

$\mathbf{E}$

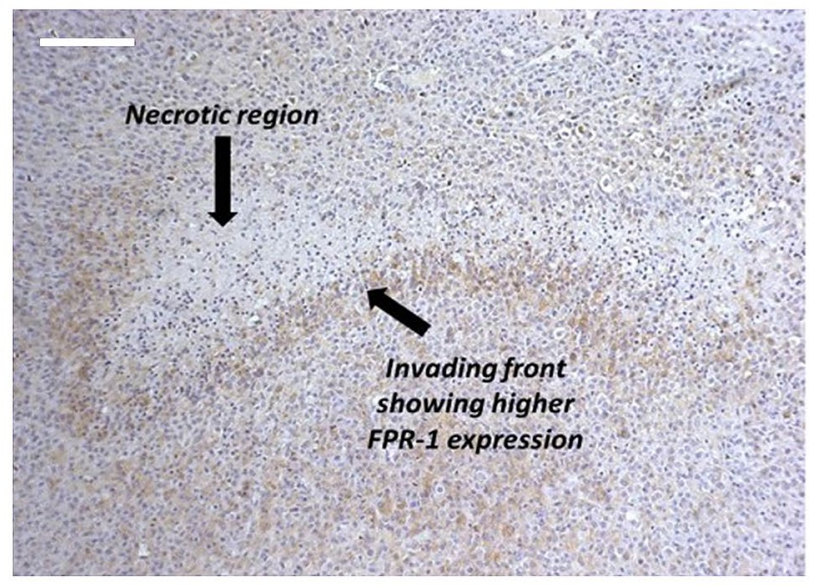

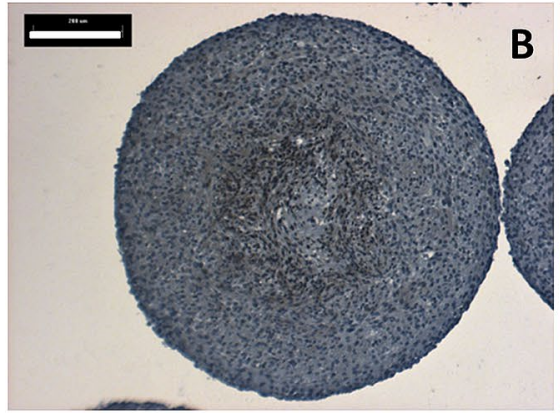
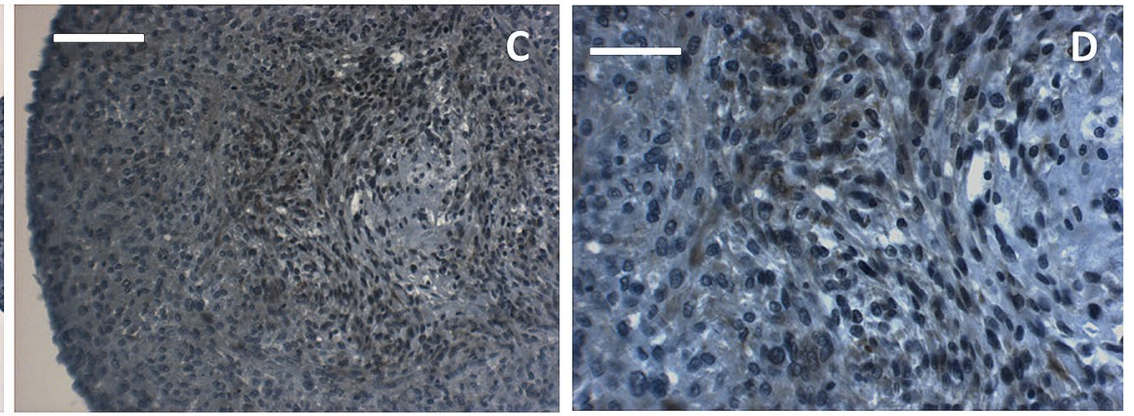

Figure 2. (A) Expression of FPR1 in U87-MG cells, cultured as monolayers, in flow cytometry over isotype control, under normal cell culture condition, serum starvation, and hypoxia $\left(^{*}<0.05,{ }^{* *}<0.005,{ }^{* *}<0.0005\right.$, $\left.{ }^{* * * *}<0.0001\right)$. (B,D) Expression of FPR1 by IHC in sections from a U87-MG multicellular spheroid (bar $=200$ micron, 100 micron and 50 micron respectively). Basophilic structure of cell was stained in blue with haematoxylin solution. (E) Expression of FPR1 by IHC in sections from a U87-MG xenotransplanted tumour tissue.

To correlate the FPR1 mediated increase in proliferation to necrosis, we also treated U87 cells with supernatant from necrotized cells which we and others ${ }^{16,33}$ have shown to contain ANXA1. U87 cells were necrotized using a freeze-thaw cycle ${ }^{33}$. The supernatant was centrifuged to remove cell debris and was then filtered. Treatment of U87 cells with this necrotic supernatant also resulted in an upsurge in proliferation, which again could be reduced upon addition of FPR1 antagonist ICT12035 (Fig. 4C).

ICT12035 reduces fMLF-induced increases in U87-MG cell invasion in 2D and 3D culture. We next looked at the role of FPR1 antagonism in modulating invasiveness of U87-MG cells in 2D and 3D culture. In a Boyden assay, using inserts coated with collagen, ICT12035 retards the invasion of U87-MG cells in a dose dependant manner (Fig. 5A,B). We also investigated effectiveness of ICT12035 on invasiveness of U87-MG multicellular spheroids. The spheroids were stained with calcein for ease of detection, embedded in collagen (with and without fMLF) and analysed at 18 and $39 \mathrm{~h}$ by microscopy. At both time points, we observed larger cross section area for the spheroids embedded in collagen containing $100 \mathrm{nM}$ fMLF. Furthermore the increase was abrogated upon addition of ICT12035 (Fig. 5C,D).

Antagonism of FPR1 modulates growth of U87-MG xenotransplanted tumour in mice. Finally, we used a subcutaneous U87-MG xenograft model to assess in vivo efficacy of ICT12035. Prior to the efficacy experiments, non-tumour bearing mice $(n=4)$ were treated with escalating doses of ICT12035 and we observed no toxicity upto a maximum dose of $100 \mathrm{mg} / \mathrm{Kg}$. Therefore, the drug was administered at $100 \mathrm{mg} / \mathrm{Kg}$ dose for five consecutive days to tumour bearing mice and the tumour growth was monitored compared to a control group ( $\mathrm{n}=8$ for both). No signs of toxicity were evident, and encouragingly, we observed a six day delay $(\mathrm{p}<0.05)$ in further growth of the tumours (Fig. 6).

\section{Materials and methods}

Cells and reagents. All cell lines were obtained from either the European Collection of Cell Cultures (ECACC) or American Type Cell Culture (ATCC) and maintained in recommended media supplemented with $10 \%(\mathrm{v} / \mathrm{v})$ foetal calf serum, $1 \mathrm{mM}$ sodium pyruvate and $2 \mathrm{mM} \mathrm{L}$-glutamine; at $37{ }^{\circ} \mathrm{C}$ in an atmosphere of $5 \%$ $\mathrm{CO}_{2}$. All cell lines are authenticated in the past three years. ICT12035 was prepared in the laboratories of the Institute of Cancer Therapeutics, University of Bradford. 
7.0
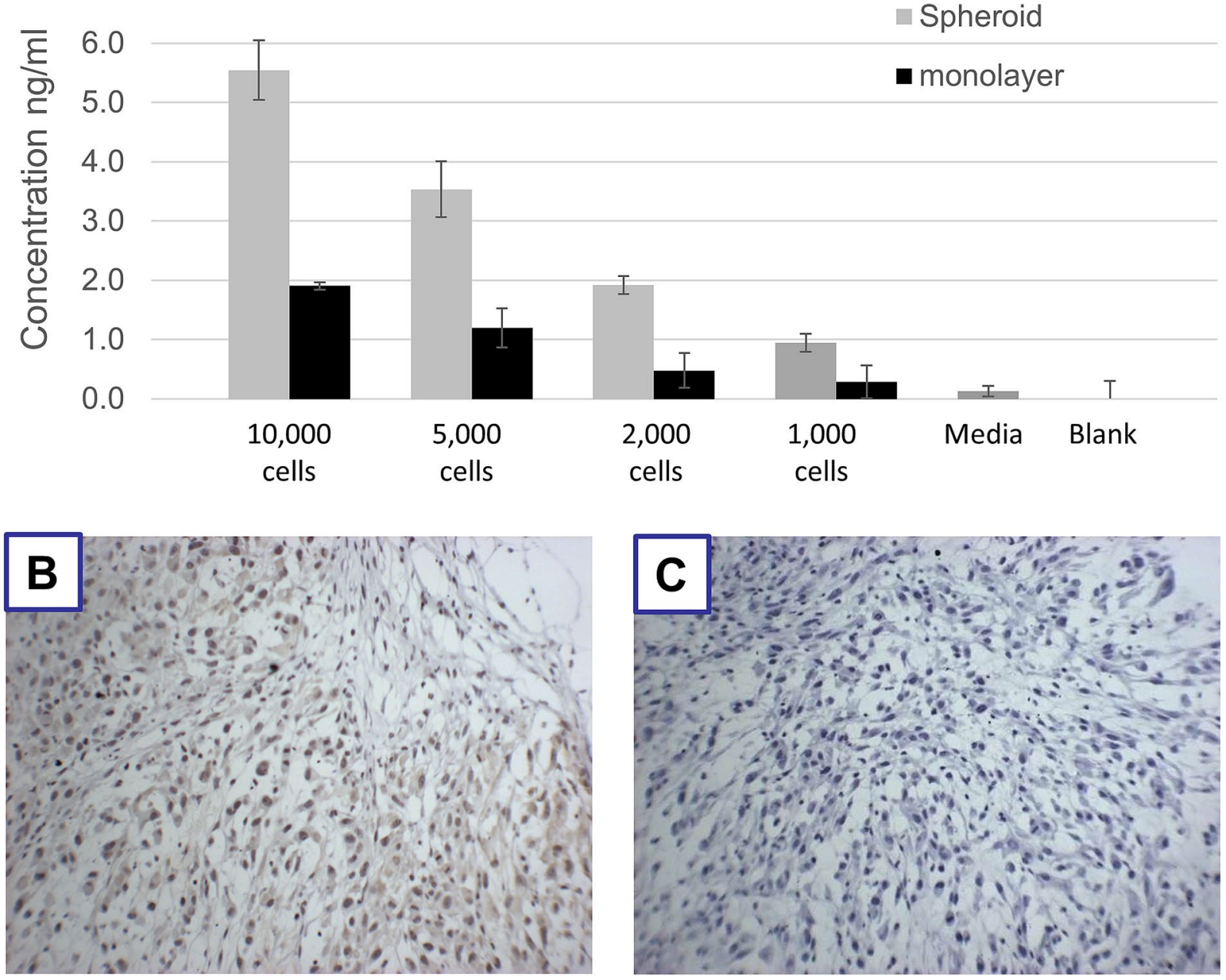

Figure 3. (A) Concentration of annexin A1 (ANXA1) released in the culture media surrounding U87-MG multicellular spheroid (grey) or over monolayer U87-MG cells (black) at different cell numbers. (B,C) Expression of ANXA1 by IHC in sections from a U87-MG xenotransplanted tumour tissue (with and without antibody). Basophilic structure of cell was stained in blue with haematoxylin solution.

Flow cytometry. Two Eppendorfs containing 30-50 $\times 10^{4}$ cells each were treated with $20 \mu \mathrm{L}$ of anti-hFPR1 (PE-conjugated, R\&D system, FAB3744P) and mouse $\mathrm{IgG}_{2 \mathrm{~A}}$ isotype control (PE-conjugated, R\&D system, $\mathrm{IC003G}$ ). Both tubes were incubated in the dark at $0{ }^{\circ} \mathrm{C}$ for $45 \mathrm{~min}$. After washing with $1 \% \mathrm{BSA}$ in PBS, the cells were analysed using a BD Accuri C6 plus flow cytometer.

Formation of spheroids. U87-MG cells $\left(1 \times 10^{6}\right.$ cells $\left./ \mathrm{ml}\right)$ were seeded into a spinner flask (F7690, Techne, Bibby Scientific Limited, Staffordshire, UK) containing $150 \mathrm{~mL}$ of RPMI-1640 containing 10\% FCS (v/v), and placed on a magnetic stirrer plate (MCS-104S, Techne, Bibby Scientific Limited, Staffordshire, UK). The mixture was stirred at a rate of $55 \mathrm{rpm}$ for 5 days.

Immunohistochemistry. The 5 micron thick sections from FFPP blocks of xenoplanted tumour tissue or spheroids were incubated with the rabbit polyclonal FPR1 primary antibody (Abcam, ab113531).

Annexin A1 quantification using ELISA. This was carried out using a sandwich enzyme-linked immunosorbent assay (ELISA) kit for human Annexin A1 purchased from Abcam (ab222868).

Preparation of necrotic supernatant. A suspension of about $55 \times 10^{4} \mathrm{cells} / \mathrm{mL}$ of U87-MG cell in PBS was subjected to 7 cycles of rapid freezing at $-80^{\circ} \mathrm{C}$ and thawing at room temperature. The mixture was centrifuged and the supernatant was filtered to remove any debris. 
A

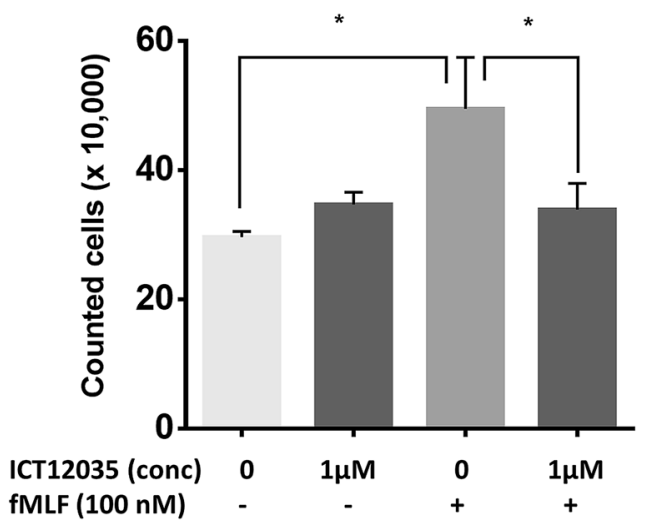

C

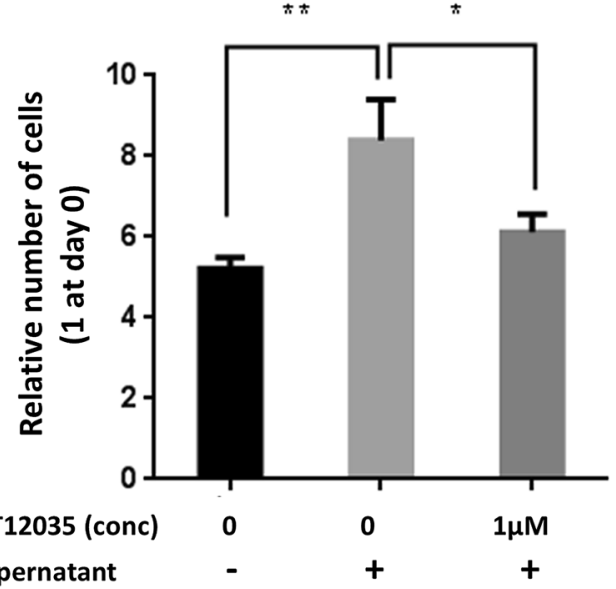

B

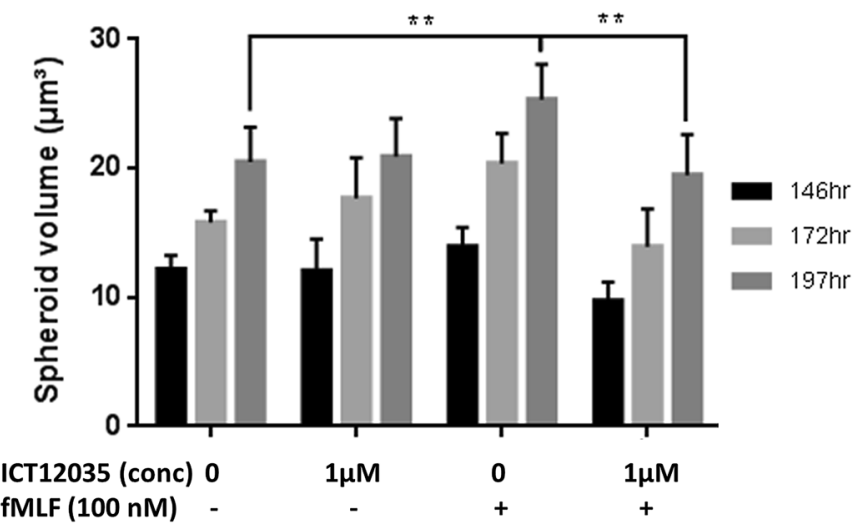

Figure 4. (A) Number of viable U87-MG cell (trypan blue exclusion) after 4 days (number of cells at $\mathrm{t}=0$ days is 10,000) $(\mathrm{n}=8)$. ICT12035 is not cytotoxic and has no effect on cell viability (second coloumn). Presence of $100 \mathrm{nM}$ fMLF significantly increases number of viable cells (third column) compared to control (first coloumn) $(\mathrm{p}=0.039)$; however, addition of ICT12035 $(1 \mu \mathrm{M})$ abrogates the fMLF induced increase in proliferation $(\mathrm{p}=0.039)\left({ }^{*}\right.$ means $\left.\mathrm{p}<0.05\right)(\mathbf{B})$ Volume of U87-MG spheroids at $146 \mathrm{~h}, 172 \mathrm{~h}$ and $197 \mathrm{~h}(\mathrm{n}=8)$. ICT12035 is not cytotoxic and has no effect on spheroid growth (second coloumn). Presence of $100 \mathrm{nM}$ fMLF significantly increases the spheroid growth (third column) compared to control (first coloumn) ( $p=0.0031$ at $197 \mathrm{~h}$ ); however, addition of ICT12035 $(1 \mu \mathrm{M})$ abrogates the fMLF induced increase in spheroid growth $(\mathrm{p}=0.0014$ at $197 \mathrm{~h})\left({ }^{* *}\right.$ means $\left.\mathrm{p}<0.005\right)(\mathrm{C})$ Relative number of U87-MG cell after 4 days (relative number of cells at $\mathrm{t}=0$ days is 1$)(\mathrm{n}=3)$. Presence of supernatant significantly increases number of cells (second column) compared to control (first coloumn) $(\mathrm{p}=0.003)$; however, addition of ICT12035 $(1 \mu \mathrm{M})$ abrogates the fMLF induced increase in proliferation $(\mathrm{p}=0.011)\left({ }^{\star}\right.$ means $\mathrm{p}<0.05 ;{ }^{* *}$ means $\left.\mathrm{p}<0.005\right)$.

Cell viability assay using MTT. Into each well of the 96 well plates, $180 \mu \mathrm{L}$ of U87-MG cell suspension $\left(5 \times 10^{4}\right.$ cells $/ \mathrm{mL}$ ) were seeded. $20 \mu \mathrm{L}$ of either PBS (as control) or ICT12035 solution in increasing concentrations were also added. Readings for each concentration were carried out in quadruplicate. Plates were incubated at $37^{\circ} \mathrm{C}, 5 \% \mathrm{CO}_{2}$, for $96 \mathrm{~h}$. Then, $20 \mu \mathrm{L}$ of a $5 \mathrm{~g} / \mathrm{L}$ solution of 3-(4,5-dimethyl-2-thiazolyl)-2,5-diphenyl$2 \mathrm{H}$-tetrazolium bromide (MTT) (Alfa Aesar, L1193) in water was added. The plate was incubated at $37^{\circ} \mathrm{C}, 5 \%$ $\mathrm{CO}_{2}$ for $4 \mathrm{~h}$ after which, the solution was carefully removed and DMSO $(150 \mu \mathrm{L})$ was added to dissolve the formazan crystals. The absorbance of each well was measured at $540 \mathrm{~nm}$ using a Multiscan Ex 96 well microplate reader (Thermo Electron Corporation, United Kingdom). The experiment was repeated in triplicate $(n=3)$.

Cell viability assay using cell counting. Into four wells of a 6-well plate, $1980 \mu \mathrm{L}$ of U87-MG cell suspension $\left(5 \times 10^{4}\right.$ cells $\left./ \mathrm{mL}\right)$ were added. To one well was added $20 \mu \mathrm{L}$ of PBS (control plate); to the second well was added $20 \mu \mathrm{L}$ of fMLF in PBS to achieve an in well concentration of $100 \mathrm{nM}$; to the third well was added $20 \mu \mathrm{L}$ of ICT12035 in PBS to achieve an in well concentration of $1 \mu \mathrm{M}$; and to the fourth well was added $10 \mu \mathrm{L}$ of each ICT12035 and fMLF in PBS to achieve an in well concentration of $1 \mu \mathrm{M}$ and $100 \mathrm{nM}$ respectively. After 5 days, each well was treated with trypsin/EDTA solution until cells were fully detached, and viable cell numbers were counted (trypan blue exclusion). The experiment was repeated in triplicate $(n=3)$.

Spheroid growth assay. Spheroids were generated by adding $200 \mu \mathrm{L}$ of a $2500 \mathrm{cell} / \mathrm{mL}$ U87-MG cell suspension into each well of an ultralow adherence 96 microtiter plate (ULA-96U from Nexcelom). Spheroids were 
A

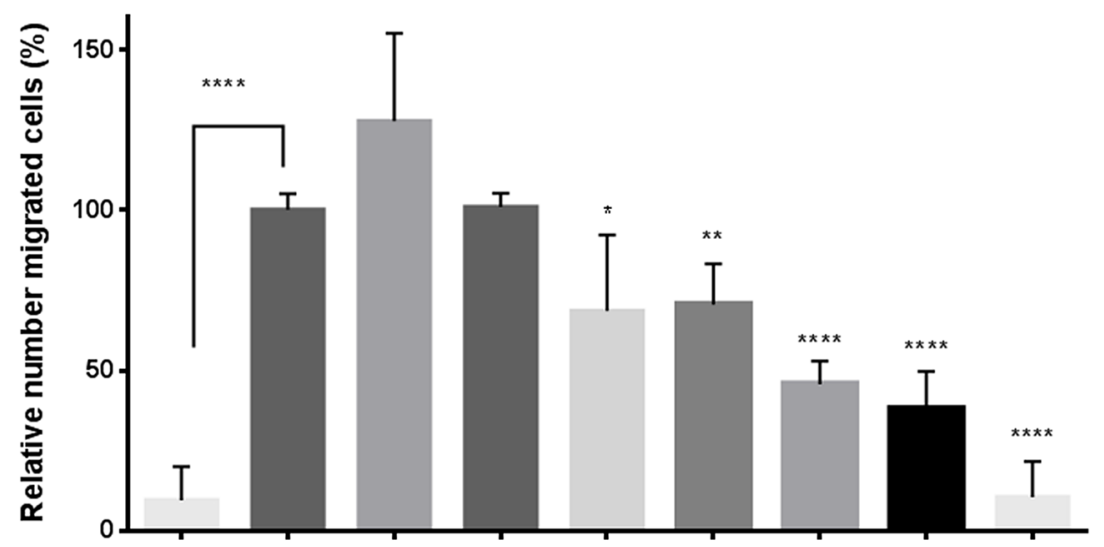

B

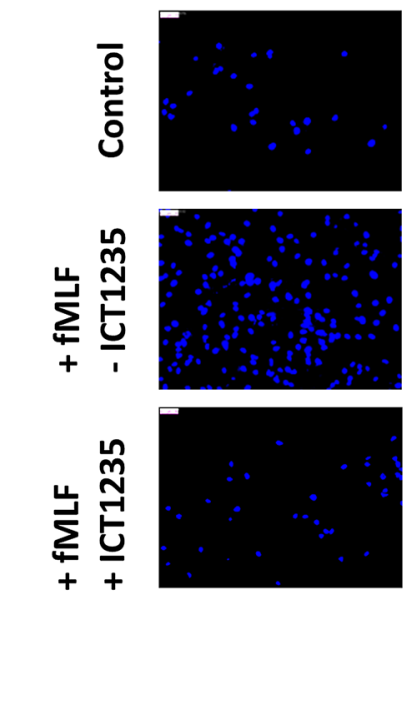

C

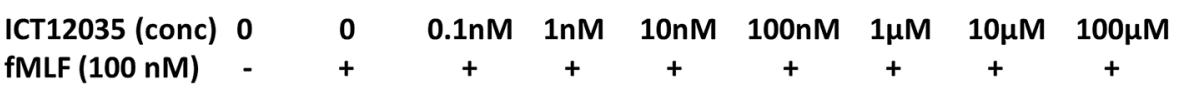

D

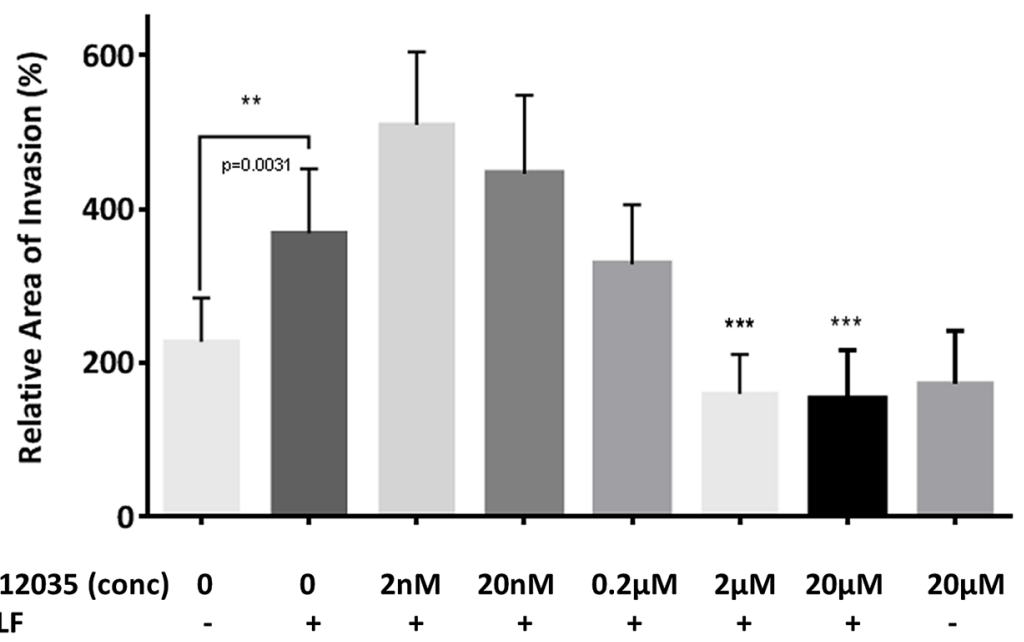

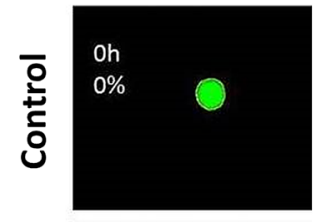
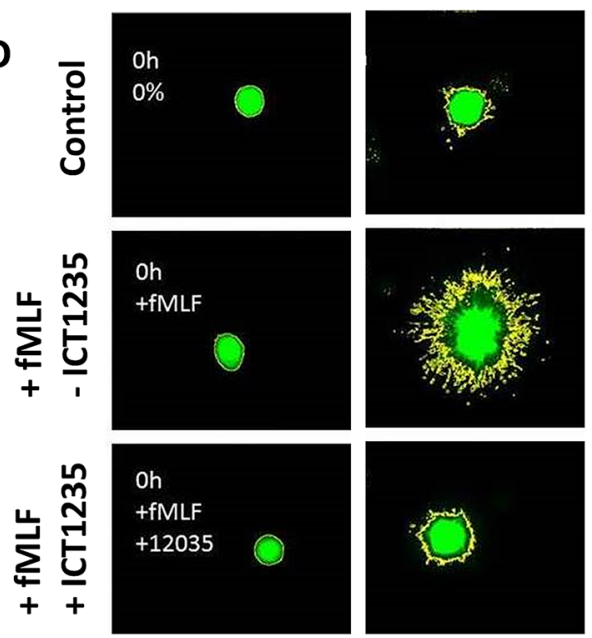

$\mathrm{t}=0 \mathrm{~h}$

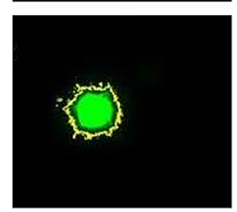

$\mathrm{t}=39 \mathrm{~h}$

Figure 5. (A) Relative number of migrated cell in a two chamber (Boyden) assay. $100 \mathrm{nM}$ fMLF significantly increases number of migrated cells (second column) compared with when no fMLF is added $(\mathrm{p}<0.0001)$. This fMLF-induced increase in migrated cells is abrogated in a dose dependent manner upon addition of ICT12035 with significant reductions at $10 \mathrm{nM}(\mathrm{p}=0.0398), 100 \mathrm{nM}(\mathrm{p}=0.0043), 1 \mu \mathrm{M}(\mathrm{p}<0.0001), 10 \mu \mathrm{M}(\mathrm{p}<0.0001)$ and $100 \mu \mathrm{M}(\mathrm{p}<0.0001)\left(^{*}<0.05,{ }^{* *}<0.005,{ }^{* *}<0.0005,{ }^{* * *}<0.0001\right)$. (B) Visual representation of differences in migration of U87-MG cells (stained with DAPI) in a Boyden assay. (C) Relative area of invasion for U87-MG spheroids embedded in collagen and maintained under cell culture medium. Addition of $9.14 \mu \mathrm{M}$ fMLF to the cell culture medium significantly increases area of invasion (second column) compared with when no fMLF is added $(\mathrm{p}=0.0031)$. This fMLF-induced increase in migrated cells is abrogated in a dose dependent manner upon addition of ICT12035 with significant reductions at $2 \mu \mathrm{M}(\mathrm{p}=0.0002)$ and $20 \mu \mathrm{M}(\mathrm{p}=0.0002)\left({ }^{*}<0.05\right.$, $\left.{ }^{* *}<0.005,{ }^{* * *}<0.0005,{ }^{* * * *}<0.0001\right)$. (D) Visual representation of differences in migration of U87-MG spheroids embedded in collagen at $0 \mathrm{~h}$ (left) and $39 \mathrm{~h}$ (right). The cells are stained with Calcein AM for ease of visualisation.

formed after $48 \mathrm{~h}$. The spheroids were treated once every $24 \mathrm{~h}$ with either PBS (as control), $100 \mathrm{nM}$ fMLF, $1 \mu \mathrm{M}$ ICT12035 (in well concentration) or both FMLF and ICT12035. The increase in the volume of spheroids were monitored for 9 days using a Celigo Imaging Cytometer using instruments software ${ }^{34}$.

Calcium mobilisation assay. This was carried out by an adaptation of the recommended protocol ${ }^{35}$. $10 \times 10^{4}$ U87-MG cells were seeded into each well of a Corning tissue culture treated 96-well black polystyrene assay plate (VWR, 734-1609). After $24 \mathrm{~h}$, the growth medium was removed and replaced with $100 \mu \mathrm{L}$ of the dye loading solution (Molecular Probes Fluo-4 NW (no wash), Invitrogen F36206). The plates were incubated at $37^{\circ} \mathrm{C}$ for $30 \mathrm{~min} .20 \mu \mathrm{L}$ of a given concentration of the antagonist in assay buffer, or plain assay buffer as control was added to each well and the plate was incubated at $37^{\circ} \mathrm{C}$ for another $30 \mathrm{~min}$. The plate was transferred into a Fluoroskan Ascent FL instrument (ThermoScientific) and the fluorescence in response to the addition of $20 \mu \mathrm{L}$ 
A

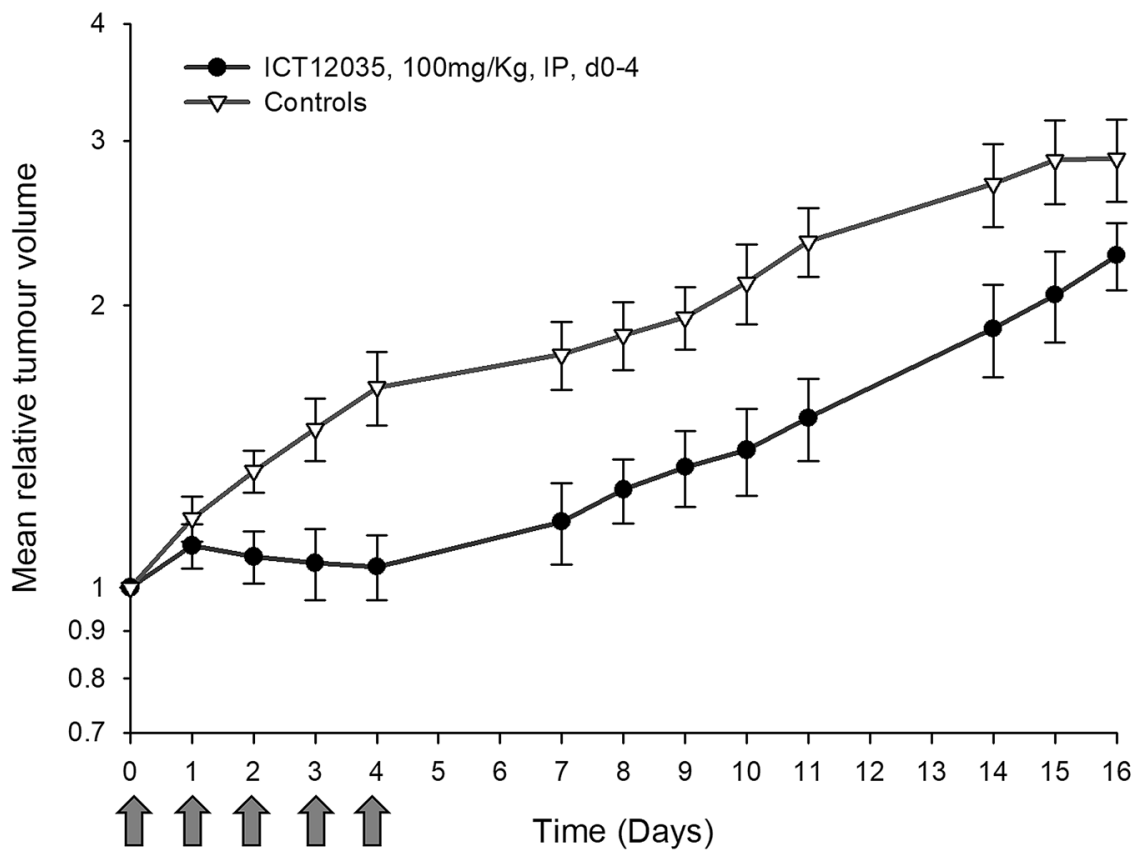

\begin{tabular}{|l|c|c|c|}
\hline \multicolumn{1}{|c|}{ Group } & $\begin{array}{c}\text { Median time to } \\
\text { RTV2 (days) }\end{array}$ & $\begin{array}{c}\text { Growth delay } \\
\text { (days) }\end{array}$ & Significance \\
\hline ICT12035, 100mg/Kg, IP, days 0-4 & 15.5 & 6.1 & $\mathrm{p}<0.05$ \\
\hline Untreated controls & 9.4 & - & - \\
\hline
\end{tabular}

B

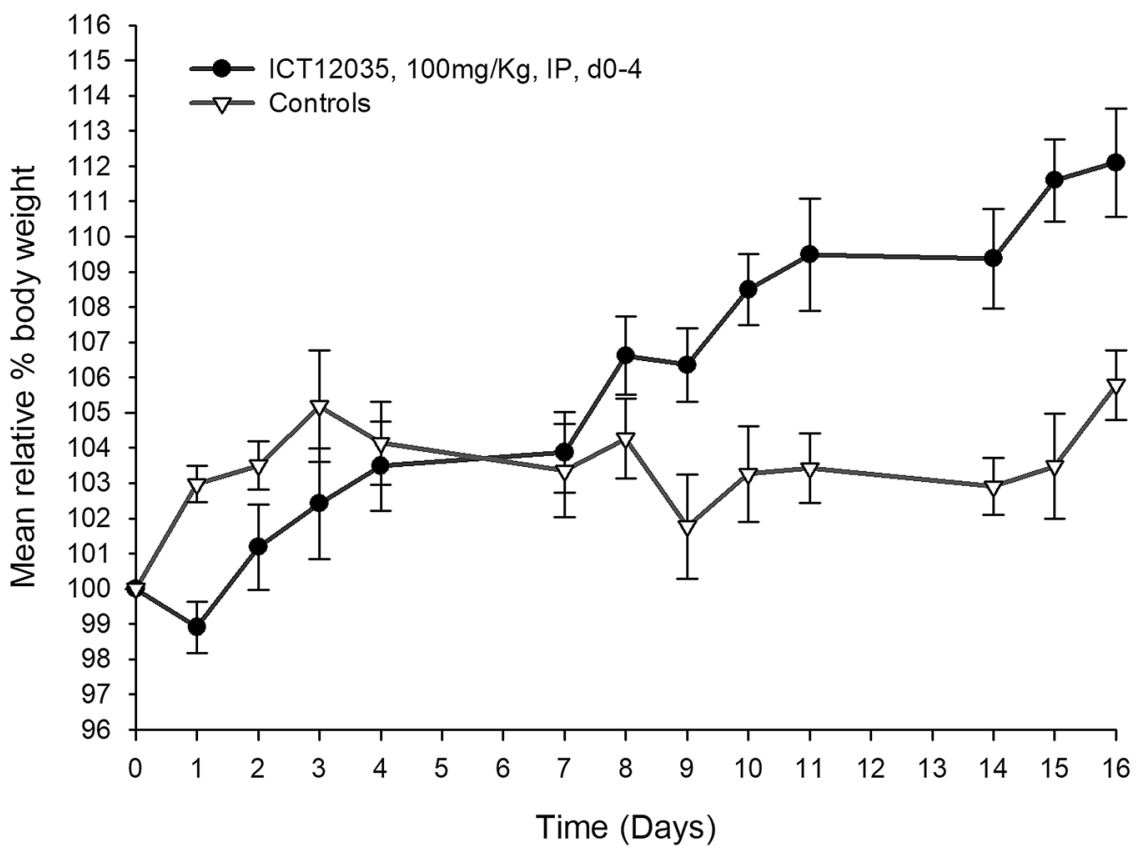

Figure 6. (A) A comparison between the growth of established xenotransplanted tumours Treatment of mice with established xenotransplanted tumours $(\mathrm{n}=8)$ with five intraperitoneally administered daily doses $(100 \mathrm{mg} / \mathrm{Kg})$ of ICT12035, resulted in a 6.1 days $(\mathrm{p}<0.05)$ delay in tumour growth compared with control; $(\mathbf{B})$ Administration of ICT12035 had no adverse effect on mice and resulted in no weight loss over the experiment period. 
of $100 \mathrm{nM}$ fMLF (in well concentration) was measured at $37^{\circ} \mathrm{C}(\mathrm{Ex} 485 \mathrm{~nm}$, Em $538 \mathrm{~nm}) . \mathrm{IC}_{50}$ is calculated as the concentration of the antagonist required to half the maximal response to fMLF. The experiment was repeated in triplicate $(n=3)$.

Chemotaxis assay. Was performed in 24-well chemotaxis chamber inserts (Corning, Product code: 3415 ). The filters were coated with $50 \mu \mathrm{g} / \mathrm{mL}$ collagen type I solution from rat tail (Sigma, C3867). To the lower chamber was added $600 \mu \mathrm{L}$ of RPMI-1640 (no serum) containing either no agonist (control) or fMLF (1.62 $\mu \mathrm{M}$ ). To the upper compartment were added $150 \mu \mathrm{L}$ of U87-MG cells $\left(6.7 \times 10^{5}\right.$ cells $\left./ \mathrm{mL}\right)$ containing the appropriate concentration of ICT12035. After $16 \mathrm{~h}$, the medium was removed and replaced with ethanol to fix the cells. Using a cotton bud, the non-migrated cells in the top compartment were gently removed from the membrane. The membrane was allowed to air dry and then was removed using a scalpel. The membrane was mounted onto a slide using mounting medium containing DAPI (Vector Labs, VECTASHIELD hard set mounting medium with DAPI). The mounted slides were viewed under a fluorescent microscope with a LeikaDM2000 camera attached. Six images from varying fields at a $20 \times$ magnification were taken. The images were analyzed using ImageJ software ${ }^{36}$. The result was given as the percentage average area of the image taken up by the DAPI stained (blue) nuclei. The experiment was repeated in triplicate $(n=3)$.

Spheroid invasion assay. $1 \mu \mathrm{L}$ of Calcein AM (4 mM in DMSO) was added to U87-MG cell suspended in $10 \mathrm{~mL}$ RPMI-1640 containing $10 \% \mathrm{v} / \mathrm{v}$ foetal calf serum. After $30 \mathrm{~min}$ incubation at $37^{\circ} \mathrm{C}$, the cell suspension was centrifuged, and the supernatant discarded. The cells were resuspended in culture medium containing methyl cellulose (v/v 20\%) to a concentration of $8 \times 10^{4}$ cells $/ \mathrm{mL}$. The lid of a $60 \mathrm{~mm}$ tissue culture dish was inverted, and $5 \mathrm{~mL}$ of PBS added to the bottom of the dish. A multi-channelled pipette was used to deposit $25 \mu \mathrm{L}$ drops (2000 cells) to the base of the lid. The lid was then inverted and placed onto the PBS-filled bottom chamber. The dish was incubated at $5 \% \mathrm{CO}_{2}$ and $37^{\circ} \mathrm{C}$ for $24 \mathrm{~h}$ or until spheroids had formed. Ice cold aqueous sodium hydroxide $(1 \mathrm{M}, 108.33 \mu \mathrm{L})$ was added to an ice cold mixture of $5 \times \mathrm{PBS}(2 \mathrm{~mL})$, distilled water $(3.56 \mathrm{~mL})$ and collagen I (from rat tail, Corning, 354236) $(4.33 \mathrm{~mL}$ ). This solution was equally divided between different Eppendorfs, and either PBS (control), fMLF to a final concentration of $9.14 \mu \mathrm{M}$, ICT12035 to a final concentration of $20 \mu \mathrm{M}$ or fMLF $(9.14 \mu \mathrm{M})$ and various concentrations of ICT12035 were added. The wells of a 96-well glass-bottomed black plate (Thermofisher, 160376) were covered with $40 \mu \mathrm{L}$ of each of the three collagen mixtures which after warming to room temperature formed a gel. Single spheroids added onto each well containing a layer of collagen gel. Another $40 \mu \mathrm{L}$ Collagen mix was gently added over the top of each spheroid to ensure the spheroid was encased in collagen gel. On top of the final layer of collagen gel was added serum free RPMI-1640 $(50 \mu \mathrm{L})$ to prevent the spheroids/gel from drying out. Images were taken at $0 \mathrm{~h}$ and $39 \mathrm{~h}$ using a LumaScope 500 and the green fluorescence filter to detect the preloaded Calcien AM within the cells. The images were analysed using ImageJ software ${ }^{36}$.

In vivo efficacy of ICT12035. All procedures were carried out under Project Licence PPL 40/3670 issued by the UK Home Office according to government legislation, following approval of the work by the local Animal Welfare Ethics Review Board at the University of Bradford, and in accordance with the UK National Cancer Research Institute Guidelines for the Welfare of Animals ${ }^{37}$. Balb/c immunodeficient nude mice (Envigo, Loughborough, UK), between the ages of 6 and 8 weeks, were used. Under brief general inhalation anaesthesia 2 to 3 $\mathrm{mm}^{3}$ fragments of U87-MG human tumor xenografts were implanted subcutaneously in the abdominal flank of the mice. Once tumour volumes reached approximately $32 \mathrm{~mm}^{3}$ (as measured by callipers), this was designated as Day 0 , and mice were randomised into two groups $(n=8)$. One group received ICT-12035 administered intraperitoneally at $100 \mathrm{mg} / \mathrm{kg}$ dose on days $0,1,2,3$ and 4 . For comparison, the control group was left untreated. Tumour volume using callipers and animal body weight were recorded through the experiment and normalised to the respective volume on the initial day of treatment (day 0). Mann-Whitney U tests were conducted to determine the statistical significance of any differences in growth rate (based on tumour volume doubling time) between control and treated groups.

\section{Discussion}

Dysregulated and improper vascularisation during tumour growth reduces access to oxygen and nutrients in regions within the tumour resulting in the formation of hypoxic/necrotic foci within tumours. This tumour necrosis plays a multifaceted and complex role in many tumours ${ }^{38-40}$. In particular, necrotised cells release many of their cytoplasmic molecules, which includes annexin A1 (ANXA1) protein, into the extracellular milieu ${ }^{30,41-44}$. The release of these proinflammatory molecules recruits leukocytes to the tumour microenvironment. Interestingly, the inflammatory response within tumours appears to both help and hinder tumour expansion ${ }^{45}$.

In addition, ANXA1 appears to have a distinct tumour promoting effect by binding and activating FPR1, the expression of which is shown to be elevated in many tumours ${ }^{13,16-22}$. The activation of FPR1 by ANXA1 promotes angiogenesis, proliferation, and invasion in a number of cancers ${ }^{13,46}$. It follows that inhibiting the activation of FPR1 by ANXA1, may have a potential role as a therapy against a number of cancers. However, to date no small molecule FPR1 antagonist has ever been investigated as a potential cancer therapy. ICT12035 is a potent and selective small molecule FPR1 antagonist ${ }^{30}$. We set out to provide the proof of the principle that a small molecule FPR1 antagonist, such as ICT12035, can have a potential as a therapy for cancers such as glioma.

A substantial body of work has already shown that the expression of FPR1 is elevated in glioma, and that the expression correlates with the stage of tumours ${ }^{16}$. More interestingly, Walenkamp has shown that the expression is enhanced under conditions within the tumour microenvironment ${ }^{32}$. Our observation (Fig. 1) that FPR1 expression is particularly elevated in the periphery of the necrotic/hypoxic core, both in a 3D spheroid model 
and in xenografted tissue, strengthens the correlation of FPR1 axis to tumour necrosis. In tissue, the so called pseudopalisades are known to be rich in HIF-1 $\alpha$, carbonic anhydrase IX and MMPs and may be considered an invading front of aggressive glioma tumours ${ }^{47}$. Although we have not yet investigated the drivers for the elevation of FPR1 expression in the periphery of the tumour core, we can speculate that may be partly due to hypoxia. Hypoxia is already known to elevate expression of another chemotactic receptor, CXCR4, in glioma ${ }^{48}$. Furthermore, we and others ${ }^{49}$ have shown that release of ANXA1 also correlates to hypoxia/necrosis which in turn may enhance FPR1 expression through an autocrine loop ${ }^{21}$.

In assessment of the efficacy of ICT12035, we opted for the use 3D in vitro models such as spheroids. 3D in vitro models are generally more advantageous and relevant than 2D models, and provide more reliable data ${ }^{50}$. Indeed, ICT12035 retards both proliferation and invasion of U87 spheroids as well as monolayers (Figs. 3 and 4). Furthermore, to show the relevance of necrosis to the FPR1-mediated expansion of gliomas, we used ICT12035 to retard increases in both proliferation and invasion of U87 spheroids as well as monolayers by necrotic U87 supernatants.

Finally, treatment of mice bearing xenotransplanted tumours with ICT12035 over 5 days, completely arrested growth of the tumours during the treatment period, but as expected, had no toxic side-effect on the mice.

Our further preliminary investigations, which we will report in due course, reveal similar effects of FPR1 activation in other cancer types. This clearly demonstrates the usefulness of FPR1 antagonists, particularly in treatment aggressive tumours. Furthermore, it is known that necrosis results from a number of treatment modalities in cancers and is hypothesised to contribute to poor clinical outcomes of current therapies ${ }^{39,51,52}$. This raises an interesting hypothesis that combining current therapies with antagonism of FPR1, at least in parts, may contribute to making them more efficacious. Therefore, further investigation of ICT12035, or other FPR1 antagonists, can open opportunities for more efficient treatment for cancers, including glioma, in due course.

\section{Data availability}

The data generated during and/or analysed during the current study are available from the corresponding author on reasonable request.

Received: 12 May 2020; Accepted: 2 September 2020

Published online: 14 October 2020

\section{References}

1. Le, Y., Sun, R., Ying, G., Iribarren, P. \& Wang, J. The role of formyl peptide receptors in microbial infection and inflammation. Curr. Med. Chem. 2, 83-93 (2003).

2. Le, Y., Murphy, P. M. \& Wang, J. M. Formyl-peptide receptors revisited. Trends Immunol. 23, 541-548 (2002).

3. Le, Y., Oppenheim, J. J. \& Wang, J. M. Pleiotropic roles of formyl peptide receptors. Cytokine Growth Factor Rev. 12, 91-105 (2001).

4. Yang, D. et al. Human dendritic cells express functional formyl peptide receptor-like-2 (FPRL2) throughout maturation. J. Leukoc. Biol. 72, 598-607 (2002).

5. Kim, S. D. et al. Functional expression of formyl peptide receptor family in human NK cells. J. Immunol. 183, 5511-5517 (2009).

6. Lee, H. Y., Lee, M. \& Bae, Y. S. Formyl peptide receptors in cellular differentiation and inflammatory diseases. J. Cell Biochem. 118, 1300-1307 (2017).

7. Chen, K. et al. Regulation of inflammation by members of the formyl-peptide receptor family. J. Autoimmun. 85, 64-77 (2017).

8. Weiß, E. \& Kretschmer, D. Formyl-peptide receptors in infection, inflammation, and cancer. Trends Immunol. 39, 815-829 (2018).

9. Schiffmann, E., Corcoran, B. A. \& Wahl, S. M. N-formylmethionyl peptides as chemoattractants for leucocytes. Proc. Natl. Acad. Sci. USA 72, 1059-1062 (1975)

10. Marasco, W. A. et al. Purification and identification of formyl-methionyl-leucyl-phenylalanine as the major peptide neutrophil chemotactic factor produced by Escherichia coli. J. Biol. Chem. 259, 5430-5439 (1984).

11. Walther, A., Riehemann, K. \& Gerke, V. A novel ligand of the formyl peptide receptor: annexin I regulates neutrophil extravasation by interacting with the FPR. Mol. Cell 5, 831-840 (2000).

12. Perretti, M. et al. Endogenous lipid- and peptide-derived anti-inflammatory pathways generated with glucocorticoid and aspirin treatment activate the lipoxin A4 receptor. Nat. Med. 8, 1296-1302 (2002).

13. Chen, K. et al. Formylpeptide receptor-2 contributes to colonic epithelial homeostasis, inflammation, and tumorigenesis. J. Clin. Invest. 123, 1694-1704 (2013).

14. Uhlén, M. et al. Proteomics. Tissue-based map of the human proteome. Science 347(6220), 1260419 (2015).

15. V18.1.proteinatlas.org FPR1 Tissue Expression. Accessed on 15 May 2020; Available online: https://www.proteinatlas.org/ENSG0 0000171051-FPR1/tissue.

16. Zhou, Y. et al. Formylpeptide receptor FPR and the rapid growth of malignant human gliomas. J. Natl. Cancer Inst. 97, 823-835 (2005).

17. Yao, X. H. et al. Chemoattractant receptors as pharmacological targets for elimination of glioma stem-like cells. Int. Immunopharmacol. 11, 1961-1966 (2011)

18. Huang, J. et al. The G-protein-coupled formylpeptide receptor FPR confers a more invasive phenotype on human glioblastoma cells. Br. J. Cancer 102, 1052-1060 (2010).

19. Snapkov, I. et al. The role of formyl peptide receptor 1 (FPR1) in neuroblastoma tumorigenesis. BMC Cancer 16, 490 (2016).

20. Li, S. Q. et al. The expression of formyl peptide receptor 1 is correlated with tumor invasion of human colorectal cancer. Sci. Rep. 7, 5918 (2017).

21. Vecchi, L. et al. Inhibition of the AnxA1/FPR1 autocrine axis reduces MDA-MB-231 breast cancer cell growth and aggressiveness in vitro and in vivo. Biochim. Biophys. Acta Mol. Cell Res. 1865, 1368-1382 (2018).

22. Jiang, X., Lei, T. \& Zhang, M. Expression and functions of formyl peptide receptor 1 in drug-resistant bladder cancer. Technol. Cancer Res. Treat. 17, 1533034618769413 (2018).

23. Cheng, T. Y. et al. Formyl Peptide receptor 1 expression is associated with tumor progression and survival in gastric cancer. Anticancer Res. 34, 2223-2229 (2014)

24. Prevete N, Liotti F, Illiano A, Pucci, P., Amoresano, A., de Paulis, A., Melillo, R.M.Formyl peptide receptor 1 suppresses gastric cancer angiogenesis and growth by exploiting inflammation resolution pathways. Oncoimmunology. 6:e1293213 (2017).

25. Prevete, N. et al. The formyl peptide receptor 1 exerts a tumor suppressor function in human gastric cancer by inhibiting angiogenesis. Oncogene 34, 3826-3838 (2015). 
26. Chen, D. L. et al. Downregulating FPR restrains xenograft tumors by impairing the angiogenic potential and invasive capability of malignant glioma cells. Biochem. Biophys. Res. Commun. 381, 448-452 (2009).

27. Yan, P. et al. The immunosuppressant cyclosporin A antagonizes human formyl peptide receptor through inhibition of cognate ligand binding. J. Immunol. 177, 7050-7058 (2006).

28. Cai, Y. et al. Contribution of FPR and TLR9 to hypoxia-induced chemoresistance of ovarian cancer cells. Onco. Targets Ther. 12, 291-301 (2018).

29. Szczepanek, J. et al. Expression profiles of signal transduction genes in ex vivo drug-resistant pediatric acute lymphoblastic leukemia. Anticancer Res. 32, 503-506 (2012).

30. Morley, A. D. et al. Lead optimisation of pyrazoles as novel FPR1 antagonists. Bioorg. Med. Chem. Lett. 22, 532-536 (2012).

31. Boer, J. C. et al. Microenvironment involved in FPR1 expression by human glioblastomas. J. Neurooncol. 123, 53-63 (2015).

32. Le, Y. et al. Expression of functional formyl peptide receptors by human astrocytoma cell lines. J. Neuroimmunol. 111, 102-108 (2000).

33. Yang, Y. et al. Annexin 1 released by necrotic human glioblastoma cells stimulates tumor cell growth through the formyl peptide receptor 1. Am. J. Pathol. 179, 2674-2675 (2011).

34. Kessel, S. et al. High-throughput 3D tumor spheroid screening method for cancer drug discovery using celigo image cytometry. SLAS Technol. 22, 454-465 (2017).

35. Schindelin, J. et al. Fiji: an open-source platform for biological-image analysis. Nat. Methods 9, 676-682 (2012).

36. https://www.thermofisher.com/order/catalog/product/F36206\#/F36206. Accessed 15 May 2020

37. Workman, P. et al. Guidelines for the welfare and use of animals in cancer research. Br. J. Cancer 102, 1555-1577 (2010).

38. Lee, S. Y. et al. Regulation of tumor progression by programmed necrosis. Oxid. Med. Cell. Longev. 2018, 3537471 (2018).

39. Amaravadi, R. K. \& Thompson, C. B. The roles of therapy-induced autophagy and necrosis in cancer treatment. Clin. Cancer Res. 13, 7271-7279 (2007).

40. Karsch-Bluman, A. et al. Tissue necrosis and its role in cancer progression. Oncogene 38, 1920-1935 (2019).

41. Biaoxue, R., Xiguang, C., Hua, L., Tian, F. \& Wenlong, G. Increased level of annexin A1 in bronchoalveolar lavage fluid as a potential diagnostic indicator for lung cancer. Int. J. Biol. Mark. 32, e132-e140 (2017).

42. Khau, T. et al. Annexin-1 signals mitogen-stimulated breast tumor cell proliferation by activation of the formyl peptide receptors (FPRs) 1 and 2. FASEB J. 25, 483-496 (2011).

43. Belvedere, R. et al. Role of intracellular and extracellular annexin A1 in migration and invasion of human pancreatic carcinoma cells. BMC Cancer 14, 961 (2014)

44. Ronquist, K. G., Ronquist, G., Larsson, A. \& Carlsson, L. Proteomic analysis of prostate cancer metastasis-derived prostasomes. Anticancer Res. 30, 285-290 (2010).

45. Rodriguez-Vita, J. \& Lawrence, T. The resolution of inflammation and cancer. Cytokine Growth Factor Rev. 21, 61-65 (2010).

46. Guo, C., Liu, S. \& Sun, M. Z. Potential role of Anxal in cancer. Future Oncol. 9, 1773-1793 (2013).

47. Brat, D. J. et al. Pseudopalisades in glioblastoma are hypoxic, express extracellular matrix proteases, and are formed by an actively migrating cell population. Cancer Res. 64, 920-927 (2004).

48. Zagzag, D. et al. Hypoxia-inducible factor 1 and VEGF upregulate CXCR4 in glioblastoma: implications for angiogenesis and glioma cell invasion. Lab. Invest. 86, 1221-1232 (2006).

49. Bizzarro, V. et al. Hypoxia regulates ANXA1 expression to support prostate cancer cell invasion and aggressiveness. Cell Adh. Migr. 11, 1247-1260 (2017).

50. Verjans, E. T., Doijen, J., Luyten, W., Landuyt, B. \& Schoofs, L. Three-dimensional cell culture models for anticancer drug screening: worth the effort?. J. Cell Physiol. 233, 2993-3003 (2018).

51. Siu, A. et al. Radiation necrosis following treatment of high grade glioma-a review of the literature and current understanding. Acta Neurochir (Wien) 154, 191-201 (2012).

52. Salah, S., Lewin, J., Amir, E. \& Abdul Razak, A. Tumor necrosis and clinical outcomes following neoadjuvant therapy in soft tissue sarcoma: a systematic review and meta-analysis. Cancer Treat Rev. 69, 1-10 (2018).

\section{Acknowledgements}

We thank Yorkshire Cancer Research for a studentship (Djevdet Ahmet), Government of Libya for studentship (Anwar Salem), University of Zarqa for a travel Grant (Haneen Basheer).

\section{Author contributions}

Experimental work was carried out by D.S.A. (Fig. 1D, Fig. 2B,E, Fig. 3B,C, Fig. 4A,C and Fig. 5), H.A.B (Figs. 1A and 2A), A.S. (Fig. 1A,C), D.L. (Preparation of ICT12035), A.A. (Preparation of ICT12035), P.W. (Fig. 4B), A.B. (Fig. 1C), J.A. (Fig. 3A), S.R. (Fig. 1B), P.A.C (Fig. 6 and preparation of xenotransplanted tissue). S.D.S., V.V. and K.A. designed experiments. Manuscript was written by K.A. and all authors reviewed the manuscript.

\section{Competing interests}

The authors declare no competing interests.

\section{Additional information}

Supplementary information is available for this paper at https://doi.org/10.1038/s41598-020-74350-z.

Correspondence and requests for materials should be addressed to K.A.

Reprints and permissions information is available at www.nature.com/reprints.

Publisher's note Springer Nature remains neutral with regard to jurisdictional claims in published maps and institutional affiliations. 
(c) (i) Open Access This article is licensed under a Creative Commons Attribution 4.0 International cc) License, which permits use, sharing, adaptation, distribution and reproduction in any medium or format, as long as you give appropriate credit to the original author(s) and the source, provide a link to the Creative Commons licence, and indicate if changes were made. The images or other third party material in this article are included in the article's Creative Commons licence, unless indicated otherwise in a credit line to the material. If material is not included in the article's Creative Commons licence and your intended use is not permitted by statutory regulation or exceeds the permitted use, you will need to obtain permission directly from the copyright holder. To view a copy of this licence, visit http://creativecommons.org/licenses/by/4.0/.

(C) The Author(s) 2020 